\title{
Revisiting WTO Fisheries Subsidies Negotiations
}

\author{
Youngjeen Cho \\ Graduate School of International Studies (GSIS), Ewha Womans University, Seoul, South Korea \\ Email:ycho@ewha.ac.kr
}

Received 1 January 2015; accepted 16 January 2015; published 21 January 2015

Copyright (C) 2015 by author and Scientific Research Publishing Inc.

This work is licensed under the Creative Commons Attribution International License (CC BY).

http://creativecommons.org/licenses/by/4.0/

(c) (i) 0 pen Access

\section{Abstract}

Fisheries subsidies negotiation was added to the negotiation agenda of the DDA largely by the concern for the depletion of fishery stocks. Some members, in particular, the Friends of Fish group countries, claimed that over-fishing and overcapacity caused by various fisheries subsidies program have resulted in the depletion of fishery stocks. Therefore, they argued that new disciplines should be introduced to address the situation. In 2007, after more than five years of negotiations, the chairman of the Rules Negotiations Group circulated a consolidated text. However, the negotiations have hardly made progress since then. This paper examines whether the Rule Negotiating Group chair's text is legally and practically appropriate to serve as a basis for the fisheries subsidies negotiations. In order to address the question, this paper presents the brief history of fisheries subsidies negotiations at the WTO. Then, it analyzes critical issues of the Rule Negotiating Group chair's text. It also explores the consolidated text of the TPP negotiations. Based on the analysis, it concludes that the basic concept and the principle of the chair's text are inconsistent with those of the ASCM, and that the structure of the text does not conform those of the ASCM and other WTO agreements. Likewise, the TPP text bears similar problems. Therefore, it is highly questionable whether WTO members and TPP parties can actually achieve the goal to conserve fishery resources. WTO members as well as TPP parties should try to address these problems, so that they can make real progress in negotiations.

\section{Keywords}

Fisheries Subsidies, World Trade Organization (WTO), Doha Development Agenda (DDA), Rules, Chairman's Consolidated Text, Agreement on Subsidies and Countervailing Measures (ASCM), Trans-Pacific Partnership (TPP)

\section{Introduction}

At the fourth WTO Ministerial Conference held at Doha, Qatar on November 2001, WTO members agreed to 
launch another round of multilateral trade negotiations known as the Doha Development Agenda (DDA). As one of the nine areas of the DDA ${ }^{1}$, rules negotiations encompass negotiations on anti-dumping, subsidies, fisheries subsidies and regional agreements. The fisheries subsidies issue was added to rules negotiations largely due to the active role of the Friends of Fish, a group of countries that include Argentina, Australia, Chile, New Zealand, the US, to name a few. These proponents claimed that fisheries subsidies should be prohibited extensively, as imminent depletion of fishery stocks on a global basis was the result of over-fishing and the fishing overcapacity caused by various subsidies programs. However, some members, such as Japan, Korea, Chinese Taipei, as well as the EU, argued that not all fisheries subsidies programs caused over-fishing and overcapacity.

In fact, the issue of fisheries subsidy is a complicated matter that encompasses three dimensions: environmental, trade, and developmental. Firstly, it is an environmental issue. It is undeniable that depletion of fishery stocks causes harm to the environment. Thus, if fisheries subsidies cause over-fishing and overcapacity that result in depletion of fishery stocks, they should be regulated. Secondly, it is a trade issue. Over-fishing may distort trade of fisheries products through displacement of imports or exports, price undercutting, price suppression, price depression, etc. If fisheries subsidies cause over-fishing, it can be argued that the subsidies have a negative effect on international trade. Thirdly, it is a developmental issue. Considering that a large number of developing and least-developed countries are engaging in the fishing industry, and are largely dependent on it, fisheries subsidies provided by relatively developed countries may have a negative impact on the socio-economic development of under-developed countries. For these reasons, the Friends of Fish members allege that a new set of rules should be introduced to regulate fisheries subsidies which cause over-fishing and overcapacity, and thus, bear a negative impact in all three dimensions. Other members argue that even though certain fisheries subsidies may have negative impacts on fishery resources, they are not the main culprit of the depletion of fishery stocks. In fact, they claim, the failure of fishing management systems is far more culpable. Therefore, the scope of prohibition should be confined to subsidies that are proven to have an adverse effect on fishery resources. They also argue that, even if fisheries subsidies are responsible for the distortion of trade, there is no reason to treat fisheries subsidies differently from other subsidies, and thus, fisheries subsidies should also be regulated by the current Agreement on Subsidies and Countervailing Measures (ASCM).

As the DDA has been paralyzed since it deadlocked in 2011, fisheries subsidies may seem a dormant issue. However, with the modest progress made at the ninth WTO Ministerial Conference held in Bali in 2013, it is carefully anticipated that the DDA may resume as early as in 2015. In addition, the consolidated text of the Trans-Pacific Partnership (TPP) negotiations contains a provision regulating fisheries subsidies, and thus, fisheries subsidies have re-emerged as a critical issue.

Against this backdrop, this paper aims to examine whether the WTO rule negotiating group chair's text is legally appropriate to serve as a basis for the fisheries subsidies negotiations. In order to address the question, this paper presents the brief history of fisheries subsidies negotiations at the WTO. Then, it analyzes the rule negotiating group chair's text and the consolidated text of the TPP negotiations. While this paper's analysis tries to acknowledge the issues involving fisheries subsidies, its focus is on the legal analysis.

\section{Brief History of Fisheries Subsidies Negotiations at the WTO}

The fisheries subsidies were added to the negotiation agenda of the DDA, as WTO members agreed to "aim to clarify and improve WTO disciplines on fisheries subsidies, taking into account the importance of these sectors to developing countries" (WTO, 2001). However, members disagreed over whether it was necessary to introduce new rules in order to regulate fisheries subsidies. After two years of tedious negotiations, they finally engaged in discussions of the nature and extent of new disciplines necessary to regulate fisheries subsidies from 2004.

Members managed to narrow the gaps in their stances and agreed on two points, in principle: first, fisheries subsidies which have negative impacts on the environment should be regulated; second, it is necessary to introduce a new set of rules to effectively regulate fisheries subsidies. However, they maintained intransigent positions on how to regulate fisheries subsidies. The Friends of Fish group members claimed that a top-down approach had to be adopted, by which all fisheries subsidies program would be prohibited with only a few excep-

\footnotetext{
${ }^{1}$ The earlier version of this paper written in Korean was published in Korean Journal of International Economic Law, Vol. 10(2), 2012. The nine negotiation areas are: non-agricultural market access (NAMA), agriculture, service, rules, trade facilitation, intellectual property rights, environment, development, and dispute settlement.
} 
tions. In contrast, Japan, Korea and Chinese Taipei suggested a bottom-up approach by which, the scope of prohibition is limited to the programs that bear negative impacts on fishery stocks, after testing the impact of each program on the environment. As members failed to resolve their differences, the negotiations resulted in a stalemate till 2005. In early 2005, members agreed to set aside the issue of the structure of regulation for a while and began assessing fisheries subsidies programs in order to ascertain whether certain program should be prohibited or not. Members shared the position that subsidies for illegal, unregulated and unreported fishing and subsidies for vessel construction that directly increased fishing capacity should be prohibited, in principle. However, with regard to subsidies for aquaculture, port facilities, process facilities, etc., their opinions were divided.

At the fifth WTO Ministerial Conference held in Hong Kong on December 2005, members reaffirmed their commitment to strengthen disciplines on fisheries subsidies (WTO, 2005). In addition, they mandated the chairman of the Rules Negotiating Group to prepare a consolidated text which would be the basis for further negotiations (WTO, 2005). Brazil, the EU, Japan, Korea, Chinese Taipei, New Zealand, Norway, and the US submitted proposals in the form of legal texts, detailing their arguments into concrete texts as part of the ASCM.

Eventually, the chairman of the Rules Negotiating Group circulated a consolidated text in November 2007. The chairman summarized the proposals submitted by members and discussions that had taken place, from his own perspectives. The new set of disciplines on fisheries subsidies was introduced as Annex VIII to the current ASCM (WTO, 2007c). Although the text adopted a bottom-up approach on the surface, it was closer to a top-down approach au fond by widening the scope of prohibited subsidies. In addition to subsidies that bear negative impacts on fishery stocks, it prohibited subsidies for vessel construction and repair, operating costs, port infrastructure and facilities, transfer fees, price support for fisheries products, income supports, etc. (WTO, 2007c). While the Friends of Fish members expressed their satisfaction with the text, Canada, the EU, and Norway who had initially supported stringent regulation of fisheries subsidies as well as Japan, Korea, and Chinese Taipei criticized the draft text for losing balance between different stances.

In December, 2008, the chairman of the Rules Negotiations Group circulated a revised version of other areas of rules negotiations, including anti-dumping and subsidies, reflecting members' opinions and comments on the previous text. However, with regard to the fisheries subsidies, the chairman circulated a "roadmap" which merely listed the issues that required further discussions. The chairman explained, as the difference in members' stances was too wide, he was unable to write a revised text. In 2010, members concentrated on the issues of prohibited subsidies and exceptions, special and differential treatment for developing countries, and fisheries management mechanisms, based on the chair's roadmap. Although members intensified negotiations in order to draft a revised text by April 2011, they failed to bridge the gaps in their positions, yet again. There were, by and large, three groups of countries that had strong stances in the negotiations, and none of them would compromise. First, the Friends of Fish members, consisting of Australia, New Zealand, the US, etc., argued that, in general, all forms of fisheries subsidies should be prohibited with a limited list of exceptions. Second, large developing countries such as Argentina, Brazil, China, India, etc., supported the Friends of Fish members' claim of the extensive prohibition of fisheries subsidies. However, they requested a broad exception for developing countries. They argued that developing countries are entitled to fisheries subsidies as part of the development implications under the DDA. Third, Japan, Korea, Chinese Taipei, the EU and Norway claimed that prohibition should be limited to fisheries subsidies that actually cause harm to the environment and that exceptions for developing countries should not be excessive. They were concerned that if a broad exception were permitted to large developing countries with strong fishing industries, the goal to protect fisheries stocks would be undermined.

In April 2011, the director general of the WTO, as the chairman of the Trade Negotiation Committee (TNC), submitted a chairman's report (WTO, 2011). While the director general's original plan was to submit revised texts for all negotiating groups, including Rules Negotiations Group, he was only able to submit a report that showed the stage of negotiations at the time. In particular, the chairman of the Rule Negotiating Group wrote that members had failed to diminish their differences not only on critical and highly divided issues, but also on technical matters related to fisheries subsidies (WTO, 2011). Since the TNC meeting in April, the DDA negotiations had hardly made any progress till December 2013. At the ninth WTO Ministerial Conference, members finally made the first modest progress in a long while by reaching agreements on the issues of trade facilitation, special treatment to products of least-developed countries, and agricultural subsidies (WTO, 2013). This has inspired somewhat optimistic anticipation that the negotiations will be invigorated in 2015, once major players of the DDA concentrate their efforts to complete the negotiations.

As mentioned above, huge gaps in major participants' stances remain even after more than a decade of nego- 
tiations. In particular, members clashed over the scope of prohibited subsidies and the extent of exceptions for developing countries, and they do not seem to be prepared to make any compromise, yet. Firstly, fisheries subsidies is a highly complicated issue that should take into account not only the trade but also the environmental and developmental implications. Secondly, it is the first time that the WTO has tried to establish a set of rule for such an issue, and it is not an easy task for members to introduce new disciplines. Furthermore, as new norms for fisheries subsidies are supposed to be a part of the current ASCM which provides rule for subsidies and countervailing measures, members were required to establish new disciplines that conform to the principles of the ASCM.

\section{Legal Analysis of the WTO Rule Negotiating Group Chair's Text}

As the chair's consolidated text on fisheries subsidies is annexed to the ASCM, the basic concepts and the principles of the ASCM should be extended to new disciplines on fisheries subsidies. However, the basic concept and the structure of the chair's text are inconsistent with those of the ASCM.

Firstly, the concept of "subsidies" in the chair's text does not match that of the ASCM. Article I.1 of the text defines eight fisheries subsidies as prohibited, while stipulating that the term "subsidies" in the article is used within the meaning of Article 1.1 and 1.2 of the ASCM (WTO, 2007a, 2007b, 2007c). By not only taking the form of an annexation to the ASCM, but also by explicitly referring to Articles 1.1 and 1.2, the text made it very clear that it adopted the concept of "subsidy" as defined in the ASCM. Therefore, the text is regulating fisheries subsidies under the current frame and disciplines of the ASCM, instead of creating a new frame or revising the current one. This means that the provision of general infrastructure is not subject to the ASCM nor to the new discipline, as the ASCM Article 1.1(a)(1)(iii) excludes governmental provisions of infrastructure based on the concept of subsidies ${ }^{2}$. In fact, even the Friends of Fish countries were of the opinion that governmental provisions of infrastructure should not be considered as subsidies although they argued for a broad prohibition of fisheries subsidies. For example, Brazil proposed, “... subsidies that are indirectly linked to harvesting activities of capture fisheries, such as fishing port facilities and inland processing facilities for fisheries products," should be treated as an exception to prohibition (WTO, 2007a). Likewise, New Zealand made a proposal that subsidies to the construction and maintenance of infrastructure for fishing communities, wharves and port facilities, and transport infrastructure, should not be prohibited (WTO, 2007b). The US also took a position similar to those of Brazil and New Zealand, and proposed the construction and maintenance of infrastructure for fishing communities should not be prohibited (WTO, 2006).

It seems that the chairman acknowledged and adhered to this principle when drafting the text. Otherwise he would have revised Article 1.1(a)(1)(iii). However, at the same time, the Article I.1(d) of the chair's text lists "subsidies in respect of, or in the form of, port infrastructure or other physical port facilities exclusively or predominantly for activities related to marine wild capture fishing” as a prohibited subsidy. By adding subsidies to port infrastructure to the list of prohibited fisheries subsidies, the chairman practically extended the scope of prohibited subsides beyond what was proposed by the Friends of Fish countries.

It can be inferred from the chair's text that he viewed port infrastructure as facilities directly linked to fishing activities, and tried to regulate subsidies provided for it. However, this is problematic in both theoretical and practical aspects. Theoretically, it is a problem since there is a conflict between the concept of subsidies that penetrates the ASCM and the chair's text. While governmental provisions of infrastructure are not even considered as a subsidy by Article 1 of ASCM, subsidies in the form of port infrastructure is prohibited by Article I.1 of the draft Annex VIII. In practice, it is not easy to differentiate between port infrastructure that operates for general use and that which operates predominantly for fishing. Except for harbors that mainly accommodate freighters and cargo ships, most ports are used by fishing vessels, passenger boats, coastal liners, etc. If the port is located in a fishing community, it is most likely used mainly by fishing vessels. And, most people engaging in coastal fishing are likely to be small-scale fishermen with relatively low incomes, and fishing communities are disadvantaged regions, more often than not. Thus, it is not proper to prohibit subsidies provided for port infrastructure without verifying the negative impact of those subsidies on fishery resource depletion, simply because certain ports are located in fishing communities. If governmental subsidies for port infrastructure were prohibited, the government's legitimate function to provide assistance to disadvantaged regions would be hindered. Also, it

\footnotetext{
${ }^{2}$ Article 1.1(a)(1)(iii) of the ASCM provides "For the purpose of [ASCM], a subsidy shall be deemed to exist if a government provides good or services other than general infrastructure (...)".
} 
would result in prohibiting the government's assistance to fishing communities, while its assistances to disadvantaged suburban area and agricultural communities are not prohibited, but even encouraged, which is a clear disparity.

Secondly, the chair's text is systemically inconsistent with the ASCM as well as other agreements of the WTO. Article IV of the chair's text stipulates that "no member shall cause, through subsidies, depletion of, or harm to, or creation of overcapacity with regard to migratory fish stocks, and that existence of such situation would be determined by taking into account available information including from other relevant international organizations." However, as Article IV does not provide any further clarification or explanation of the term "harm," it is unclear what it means. Does it mean harm done to the environment, to domestic industry, or to both? In addition, it is not clear whether it means harm done to a specific member or whether it also includes potential harm. If it means the latter, any member can file a complaint against another member's subsidies program for harm done to certain fishery stocks or certain regions, even when its own environment or industry was not harmed. Also, the chair's text fails to resolve issues such as how to determine and assess the level of harm. Considering that the ASCM explains the meaning of "adverse effect" and "serious prejudice" in detail, the chair's text should further elaborate on the meaning of "harm" ${ }^{3}$. If the ASCM and the draft Annex VIII were declaratory in nature, the ambiguity in terms would not be so problematic. However, once adopted, the draft Annex VIII would consist compulsory rules that apply to all WTO members. In case of violation, the measure would be adjudicated through the WTO dispute settlement system.

In addition, Article IV provides a legal basis for a member to file a complaint when other members inflict harm or created overcapacity of straddling fish stocks in which it has an interest. However, once again it lacks clarification on the issue of proving causal link between subsidies and the depletion of fishery resources. In fact, there are various reasons that may cause a depletion of fishery resources other than subsidies resulting in over-fishing and overcapacity. And the depletion caused by other factors should not be attributed to subsidies. Also, in order to hold subsidies responsible for the depletion, it should be established at least as a material reason, if not the sole cause for the depletion. However, as the chair's text did not elaborate on these issues, there is a risk that the subsidy is assumed to have caused the depletion of certain fish stock. It is not only unfair but also legally improper to hold certain members responsible without establishing the causal link between their measures and the harm done. Furthermore, this is more problematic considering that the ASCM, as well as the Agreement on Implementation of Article VI of the General Agreement on Tariffs and Trade 1994 (Anti-Dumping Agreement) and the Agreement on Safeguards provide elaborated guideline on determining causal link ${ }^{4}$.

Moreover, Article IV stipulated that the existence of harm shall be determined by taking into account the data from relevant international organizations. However, this may end up causing a serious risk to the environment, in practice. Currently, quite a number of countries, most of whom are also WTO members, have joined various regional fishery management organizations (RFMOs), and voluntarily report to the RFMOs their fishing activities such as amounts of catch of specific stock, fishery condition, and condition of fish stocks. Then, the RFMOs analyze conditions of various fishery resources, based on the data voluntarily provided, and try to conserve fishery resources at risk. Even when members have over-caught or failed to implement the agreement adopted at the RFMOs, they would still report truthfully, because they understand that the purpose of their reports is to ensure proper monitoring required for the conservation of fishery resources. However, once members think that they could be liable for what they have done, it is highly possible that they would be tempted to report false data or not to report. And then, without proper data, it would be difficult to identify and assess the actual conditions of fishery resources.

Once provisions of fisheries subsidies are challenged at the WTO, the issue of implementation may follow. Should a respondent not suspend or withdraw the subsidies program at dispute, and thus, fails to implement the recommendation of the Dispute Settlement Body (DSB), it would be obliged to provide compensation ${ }^{5}$. If it fails to compensate to the complainant, the latter could retaliate against the former with the DSB's authorization ${ }^{6}$. In the case of retaliation, the level of retaliation should be equivalent to the level of harm ${ }^{7}$. However, with respect to disputes on fisheries subsidies, it is difficult to assess that of retaliation. It is unclear how to assess the harm

\footnotetext{
${ }^{3}$ More generally, see ASCM Article 5, Anti-Dumping Agreement Article 3, and Safeguard Agreement Article 4.

${ }^{4}$ See Anti-Dumping Agreement Article 3.5 and Safeguard Agreement Article 4.2.

${ }^{5}$ Understanding on Rules and Procedures of Governing the Settlement of Disputes (DSU), Art.22.

${ }^{6} I d$.

${ }^{7} I d$.
} 
done to the environment in monetary terms. Also, would it be possible for a complainant to retaliate against a respondent, when the complainant challenged another member's subsidy program because of a harm done to environment as a common asset, even though there had been no direct harm to its fishing industry? If yes, what should the level of retaliation? These are only a few examples of the complicated issues that could possibly arise, of which the chair's text fails to address.

Fisheries subsidies are also discussed at the TPP talks among twelve countries ${ }^{8}$, and the environment chapter of the consolidated texts is known to contain an article regulating fisheries subsidies ${ }^{9}$. Article SS.16.6 provides that "no party shall grant or maintain subsidies that target the fishing of fish stocks that are in an overfished condition," while referring to Articles 1.1 and 2 of the ASCM (TPP, 2013). The article bears problems similar to those of the rule negotiating group chair's text. First, the scope of prohibition is overly broad; in fact, it is even broader than that of the chair's text, as the article prohibits fisheries subsidies targeting the fishing of fish stocks in an overfished condition, without requiring any actual over-fishing or over capacity as a result of the subsidies. This may end up prohibiting almost all kinds of fisheries subsidies, as most fisheries subsidies target the fishing of fish stocks in an overfished condition, directly or indirectly, to a certain extent. It is not surprising that the countries participating in the TPP have introduced the overall prohibition of fisheries subsidies. All participants of the TPP, except for Brunei Darussalam and Japan, were proponents of stronger regulation of fisheries subsidies at the DDA talks. As members of the WTO are allowed to depart from the WTO rules, and introduce stronger rules or provide further market access in regional trade agreements (RTAs), strengthening the rules of fisheries subsidies per se is not problematic. However, the consolidated text of the TPP, on the one hand, introduces an overly broad scope of prohibition, and on the other hand, refers to the definition of "subsidies" provided by the ASCM, which raises the issue of inconsistency in the basic concepts. Thus, it is highly questionable how the provision would be interpreted and applied in actual disputes.

\section{Conclusion}

This paper deals with the DDA negotiations on fisheries subsidies where the members have tried to explore new disciplines for fisheries subsidies. Fisheries subsidies negotiations were launched largely by the concern for the depletion of fishery stocks. Some members, in particular, the Friends of Fish countries, claimed that over-fishing and overcapacity caused by various fisheries subsidies program have resulted in the depletion of fishery stocks, and insisted that new disciplines should be introduced to address this situation.

In November 2007, after more than five years of negotiations, the chairman of the Rules Negotiations Group circulated a draft text for the fisheries subsides by summarizing all proposals submitted by that time, from his own perspective. The draft text was written in the form of an annex to the ASCM. While the text was intended to provide a basis for further negotiations, it bears a few problems. First, by prohibiting subsidies provided to port infrastructure and port facilities, the draft text is in conflict with the ASCM on the basic concept of "subsidies". In addition, the draft text does not provide any clear guidance in interpreting the term "harm", determining causal link between subsidies and harm, or implementing the DSB's recommendations. Furthermore, it is not consistent with the relevant parts of the ASCM or other WTO Agreements. This is not only a legal and theoretical problem but also a practical problem, as there is no guarantee that the draft text will effectively aid the conservation of fisheries stocks, even if it were adopted by a consensus of the WTO members. Moreover, the consolidated text of the TPP negotiations bears similar problems. While it departs from the basic concept and the principle of the ASCM, it still refers to the ASCM in defining "subsidies".

Although the DDA negotiations are deadlocked now, members may make a last ditch effort and invigorate the talks in the near future. Once the talks have resumed, members should try to resolve these issues, so that they can make real progress in fisheries subsidies negotiations.

\section{References}

TPP (2013). Environment Chapter-Consolidated Text. https://wikileaks.org/tpp-enviro/

\footnotetext{
${ }^{8}$ The twelve countries are: Australia, Brunei Darussalam, Canada, Chile, Japan, Malaysia, Mexico, New Zealand, Peru, Singapore, the US, and Vietnam.

${ }^{9}$ As of October 2014, the consolidated text of the TPP negotiations is not disclosed officially. However, the text as revised on 24 November 2013 was released to public on 15 January 2014 by Wikileaks. http://wikileaks.org
} 
WTO (2001). Ministerial Declaration, WT/MIN(01)/DEC/1, 20 November 2001.

WTO (2005). Doha Work Programme-Ministerial Declaration Adopted on 18 December 2005, WT/MIN(05)/DEC, 22 December 2005.

WTO (2006). Fisheries Subsidies_Exhaustive List of Non-Prohibited Fisheries Subsidies: Paper from New Zealand, TN/ RL/GEN/141, 6 June 2006.

WTO (2007a). Possible Disciplines on Fisheries Subsidies_Paper from Brazil, TN/RL/GEN/79/Rev.4, 13 March 2007.

WTO (2007b). Fisheries Subsidies_Proposed New Disciplines; Proposal from the US, TN/RL/GEN/145, 22 March 2007. WTO (2007c). Draft Consolidated Chair Texts of the AD and SCM Agreements, TN/RL/W/213, 30 November 2007.

WTO (2008). New Draft Consolidated Chair Texts of the AD and SCM Agreements, TN/RL/W/236, 19 December 2008. WTO (2011). Cover Note by Chair, TN/C/13, 21 April 2011.

WTO (2013). Bali Ministerial Declaration adopted on 7 December 2013, WT/MIN(13)/DEC, 11 December 2013. 
Scientific Research Publishing (SCIRP) is one of the largest Open Access journal publishers. It is currently publishing more than 200 open access, online, peer-reviewed journals covering a wide range of academic disciplines. SCIRP serves the worldwide academic communities and contributes to the progress and application of science with its publication.

Other selected journals from SCIRP are listed as below. Submit your manuscript to us via either submit@scirp.org or Online Submission Portal.
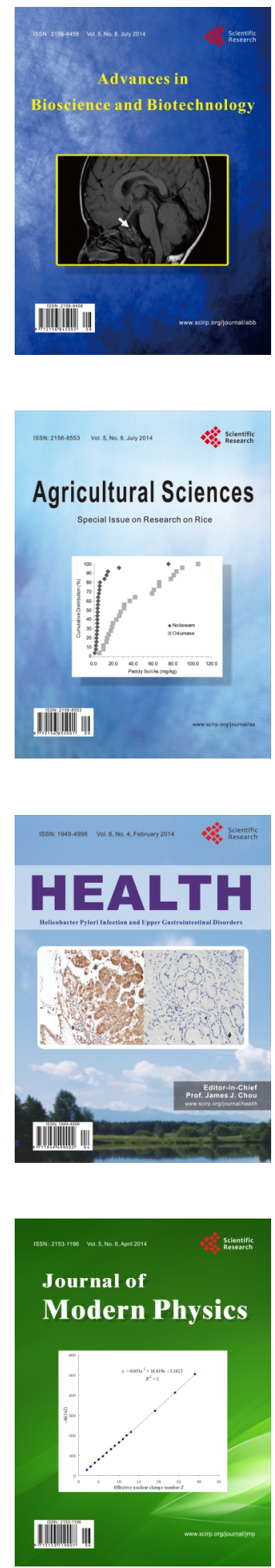
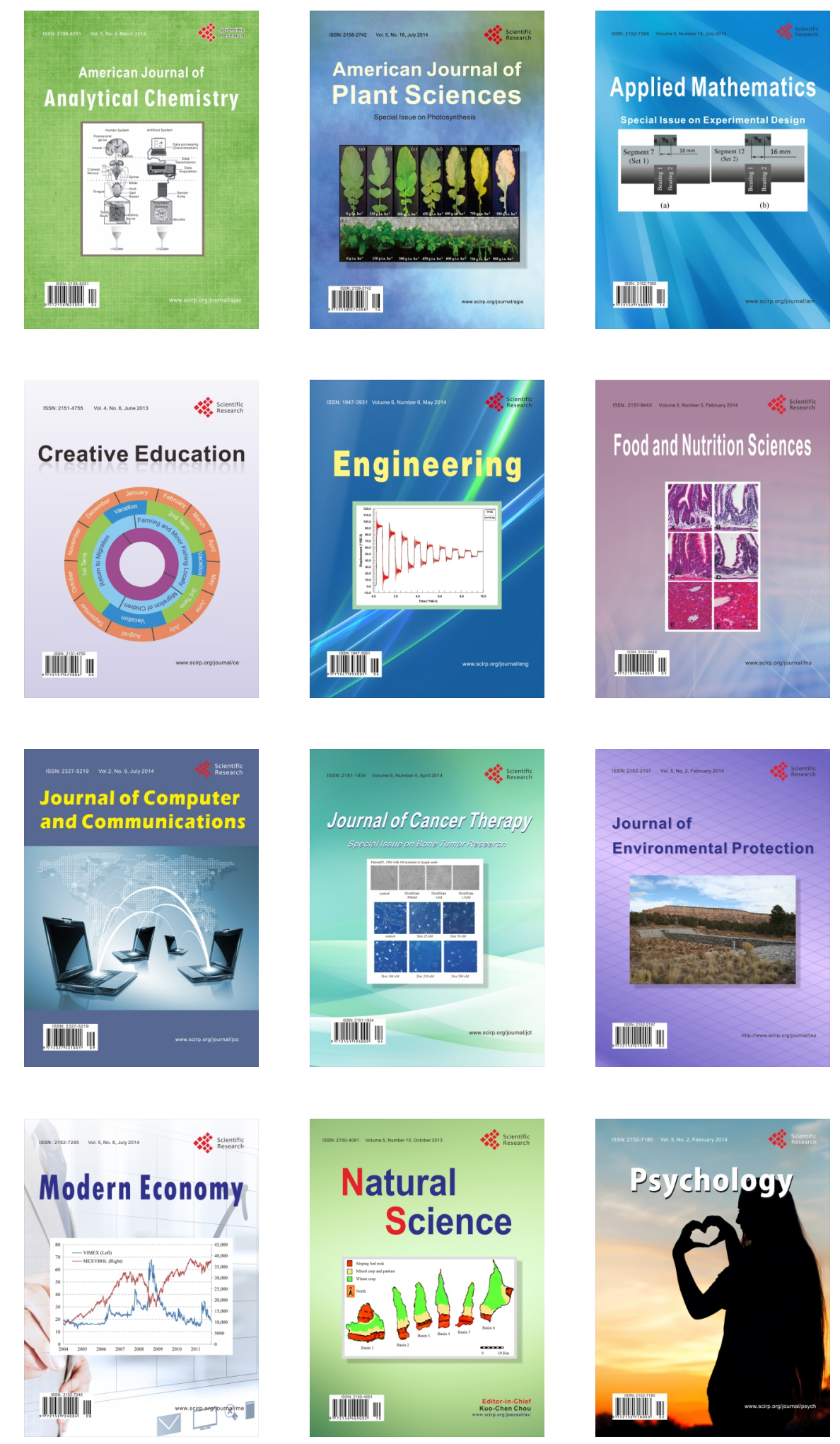